\title{
Pengaruh Kinerja Perusahaan terhadap Kebutuhan Modal Kerja Perusahaan Manufaktur yang Terdaftar di Bursa Efek Indonesia
}

\author{
Eka Putra Pratama ${ }^{\mathrm{a}^{*}}$, Arif Darmawan ${ }^{\mathrm{b}}$ \\ a Jurusan Manajemen Bisnis, Politeknik Negeri Batam, ekapratamaputra30@gmail.com, Indonesia \\ bJurusan Manajemen Bisnis, Politeknik Negeri Batam,darmawan@polibatam.ac.id, Indonesia
}

\begin{abstract}
This study aims to determine the effect of company performance proxied with ROA, sales growth, firm size, firm age, assets tangibility, operating cash flow and leverage to working capital requirement (WCR). The data used are secondary data of manufacturing companies listed in Indonesia Stock Exchange (IDX) period 2012-2015. Sampling method using purposive sampling technique. The analysis used is descriptive statistic, panel data regression. Result of research found ROA have a significant positive effect to working capital requirement. Firm size, assets tangibility, and leverage have a significant negative effect on working capital requirement. Sales growth, firm age, and operating cash flow have no effect on working capital requirement. This research can be used as a consideration of the company to further improve the performance of the company and pay attention to the factors of determination of working capital needs, so that the working capital needs of the company can be fulfilled and optimal.
\end{abstract}

Keywords: working capital requirement, company performance

\section{Pendahuluan}

Perusahaan menjalankan setiap aktivitasnya, dituntut dapat memahami sumber-sumber dana yang akan digunakan. Sumber dana tersebut merupakan pendukung dari modal kerja perusahaan, dengan begitu sudah menjadi tanggung jawab manajemen perusahaan untuk mengelolanya sehingga diharapkan dapat memaksimalkan profitabilitas serta memberikan kepuasan yang maksimal kepada para pemegang saham (Fahmi, 2015). Menurut Singh \& Kumar (2017) setiap perusahaan memerlukan manajemen yang efisien dari pegelolaan modal kerja yang dimiliki untuk mempertahankan tingkat pertumbuhan. Menurut Wasiuzzaman (2015) modal kerja yang efisien merupakan salah satu kondisi keberhasilan perusahaan.
Manajemen modal kerja sangat penting bagi perusahaan. Modal kerja yang besar dari kebutuhan yang ada akan mengakibatkan tidak efisiennya penggunaan modal kerja tersebut dan sebaliknya apabila modal kerja yang kecil atau sedikit juga akan mengganggu jalannya aktivitas perusahaan (Alexandri, 2009). Menurut Weston \& Copeland (1985), modal kerja merupakan investasi perusahaan dalam bentuk uang tunai, piutang, persediaan, dan surat berharga. Hal berbeda diungkapkan oleh Singhania (2017) bahwa modal kerja merupakan ukuran likuiditas dan mendefinisikan kondisi jangka pendek dari perusahaan. Perusahaan yang memiliki modal kerja yang cukup dapat dengan mudah melunasi segala kewajibannya dan mendukung segala aktivitas operasional yang ada.

\footnotetext{
*Corresponding author. E-mail: ekapratamaputra30@gmail.com
} 
Mayoritas studi empiris terkait kebutuhan modal kerja perusahaan diukur menggunakan cash conversion cycle (CCC). Jose et al. (1996), Shin \& Shoenen (1998), Lyroudi \& Lazaridis (2002), Deelof (2003), Abuyazed (2010), Nobane (2011), Yazdanfar \& Ohman (2014) menyatakan bahwa CCC berpengaruh terhadap kinerja perusahaan. Studi empiris telah dilakukan untuk mengidentifikasi faktorfaktor determinasi kebutuhan modal kerja. Akinlo (2010) mengungkapkan faktor-faktor determinasi kebutuhan modal kerja seperti sales growth, operating cycle, leverage dan ukuran perusahaan adalah driver utama dari kebutuhan modal kerja (WCR).

Penelitian ini merupakan replikasi dari penelitian yang dilakukan oleh Singh \& Kumar (2017) yang menguji pengaruh profitabilitas, leverage, growth opportunities, umur perusahaan, asset tangibility, ukuran perusahaan dan operating cash flow terhadap kebutuhan modal kerja pada UKM manufaktur di India. Perbedaan penelitian ini dengan penelitian sebelumnya adalah sampel yang digunakan yaitu perusahaan manufaktur yang terdaftar di Bursa Efek Indonesia. Perusahaan manufaktur merupakan perusahaan yang memiliki modal kerja yang besar, hal ini dikarenakan untuk proses operasional seperti produksi membutuhkan aktiva yang maksimal untuk menghasilkan produk yang sesuai dengan kebutuhan yang ada.

\section{Tinjauan Literatur}

\section{Teori agensi}

Menurut Jensen \& Meckling (1976), teori agensi menjelaskan hubungan antara manajemen perusahaan dengan principal (pemegang saham). Manajemen adalah pihak yang diberi wewenang untuk mengelola perusahaan demi kepentingan pemegang saham. Manajemen perusahaan yang telah diberi wewenang, maka pihak manajemen harus dapat mempertanggungjawabkan semuanya kepada pemegang saham. Dalam pengelolaan modal kerja, manajemen harus bisa mengelolanya dengan baik sehingga diharapkan menjadi efisien sehingga dapat memaksimalkan kinerja perusahaan dan memberikan kepuasan yang maksimal kepada para pemegang saham (Fahmi, 2015).

\section{Teori pecking order}

Menurut Myers \& Majluf (1984), pecking order merupakan kondisi perusahaan yang lebih mengutamakan pendanaan ekuitas internal daripada pendanaan ekuitas eksternal. Dalam memperoleh kebutuhan modal kerja, perusahaan cenderung menggunakan pendanaan dari internal perusahaan yaitu laba ditahan. Hal ini disebabkan oleh penggunaan sumber dana internal lebih kecil risikonya daripada menggunakan sumber dana eksternal seperti menerbitkan saham baru dan hutang. Pendanaan eksternal diperlukan, maka perusahaan harus siap dengan segala risiko yang ada seperti kewajiban membayar bunga dan dividend.

\section{Kinerja perusahaan}

Kinerja perusahaan menunjukkan kemampuan perusahaan untuk dapat menghasilkan keuntungan atau prestasi yang dicapai oleh perusahaan dalam periode tertentu (Subramanyam \& Wild, 2010). Diharapkan perusahaan yang memperhatikan faktorfaktor determinasi dari kebutuhan modal kerja membuat modal kerja perusahaan dapat meningkat dan membuat kinerja perusahaan menjadi lebih baik. Kinerja perusahaan yang meningkat dari sebelumnya menunjukkan bahwa perusahaan tersebut memiliki prospek yang baik dan jika menurunnya kinerja perusahaan maka perlu dilakukan evaluasi. Evaluasi perlu dilakukan untuk memperbaiki segala kesalahankesalahan yang terjadi.

\section{Return on assets}

Menurut Brigham \& Houston (2007), return on assets (ROA) merupakan pengembalian atas total aktiva yang dihitung dengan membandingkan laba bersih yang tersedia dengan total aktiva. Menurut Fahmi (2015), ROA merupakan rasio ukuran tentang efektivitas manajemen dalam mengelola aktivanya. ROA digunakan untuk mengetahui efektivitas manajemen yang ditujukan pada besar dan kecilnya tingkat keuntungan yang diperoleh perusahaan. Rasio ini diperoleh dari informasi akuntansi dari laporan keuangan. Rasio ini kemudian dibandingkan dengan rata-rata industri, semakin tinggi ROA maka menggambarkan efektivitas pengelolaan dari aktiva yang ada dan kinerja perusahaan semakin baik karena tingkat pengembalian atas investasinnya semakin besar. 


\section{Sales growth}

Menurut Fahmi (2015), sales growth (SG) merupakan rasio yang mengukur kemampuan perusahaan dalam mempertahankan posisinya di pasar. Pertumbuhan penjualan menandakan keberhasilan perusahaan dalam berinvestasi di masa lalu dan dapat dijadikan prediksi pertumbuhan di masa depan. Diharapkan dengan adanya pertumbuhan penjualan maka kas dan piutang perusahaan dapat meningkat sehingga akan menjadi tambahan dalam modal kerja yang ada pada perusahaan.

\section{Operating cash flow}

Laporan arus kas melaporkan arus kas masuk dan arus kas keluar selama periode tertentu. Laporan arus kas digunakan manajemen perusahaan untuk mengevaluasi kegiatan operasional dan untuk merencanakan aktivitas investasi dan pembiayaan di masa depan. Arus kas operasi merupakan aktivitas utama pada perusahaan karena meliputi transaksi yang tergolong sebagai penentu besarnya laba atau rugi. Laba yang tinggi pada perusahaan dapat dimanfaatkan sebagai modal kerja pada periode selanjutnya (Herry, 2009).

\section{Leverage}

Menurut Brigham \& Houston (2007), leverage (LEV) merupakan rasio yang mengukur sejauh mana segala aktivitas pendanaan yang digunakan oleh perusahaan menggunakan hutang. Penggunaan hutang yang terlalu tinggi dapat membahayakan perusahaan karena akan menimbulkan risiko yang tinggi. Perusahaan harus bisa menyeimbangkan berapa kemungkinan hutang yang akan diambil dan memperhatikan sumber hutang tersebut.

\section{Modal kerja}

Menurut Kasmir (2003), modal kerja merupakan modal yang digunakan perusahaan untuk membiayai operasional atau aktivitas lainnya. Modal kerja juga diartikan sebagai investasi yang ditanamkan dalam aktiva lancar atau aktiva jangka pendek seperti kas, persediaan, surat berharga, piutang dan aktiva lancar lainnya serta digunakan untuk beberapa kali kegiatan dalam satu periode. Menurut Singh \& Kumar (2017) kebutuhan modal kerja berkaitan dengan pengelolaan kas, piutang, marketable securities dan persediaan. Dengan pengelolaan yang efektif dari komponen kebutuhan modal kerja maka dapat membantu perusahaan dalam mewujudkan manajemen modal kerja yang optimal untuk keberlangsungan hidup perusahaan di masa depan. Perusahaan yang kekurangan modal kerja atau penegelolaan dari manajemen modal kerja yang buruk maka akan berdampak negatif bagi perusahaan.

Penelitian terkait kebutuhan modal kerja yang mengidentifikasi faktor-faktor determinasi kebutuhan modal kerja telah dilakukan. Chio et al. (2006) melakukan penelitian tentang berbagai faktor penentu kebutuhan modal kerja berdasarkan sampel 19.180 perusahaan di Taiwan. Hasil penelitian tersebut menunjukkan debt ratio dan operating cash flow (OCF) berpengaruh negatif terhadap terhadap kebutuhan modal kerja. Kinerja, usia dan ukuran perusahaan berpengaruh positif terhadap kebutuhan modal kerja namun, pertumbuhan perusahaan tidak signifikan terhadap kebutuhan modal kerja.

Narender et al. (2008) melakukan penelitian menggunakan kerangka penelitian Chio et al. (2006) dengan sampel perusahaan semen di India. Hasil penelitian tersebut menunjukkan ukuran perusahaan dan OCF berpengaruh positif terhadap kebutuhan modal kerja. Pertumbuhan perusahaan dan siklus bisnis berpengaruh negatif terhadap kebutuhan modal kerja namun, leverage tidak signifikan terhadap kebutuhan modal kerja.

Akinlo (2012) melakukan penelitian faktor determinasi dari kebutuhan modal kerja pada perusahaan non keuangan di Nigeria sebanyak 66 perusahaan. Hasil penelitian menunjukkan siklus operasi, sales growth, aktivitas ekonomi dan ukuran perusahaan berpengaruh positif terhadap kebutuhan modal kerja. Leverage secara signifikan berpengaruh negatif terhadap kebutuhan modal kerja. Penelitian yang sama juga dilakukan oleh Onaolapo \& Kajola (2015) melakukan penelitian faktor determinasi kebutuhan modal kerja pada perusahaan non keuangan di Nigeria yang terdaftar di Bursa Efek Nigeria. Ukuran perusahaan, ROA dan siklus operasi berpengaruh positif terhadap kebutuhan modal kerja perusahaan serta LEV berpengaruh negatif terhadap kebutuhan modal kerja. Growth dan aktivitas ekonomi tidak signifikan terhadap kebutuhan modal kerja.

Wasiuzzaman \& Arumugam (2013) melakukan penelitian determinasi dari modal kerja investasi dengan menggunakan data panel dari 192 perusahaan yang terdaftar di Bursa Malaysia. Hasilnya menunjukkan bahwa profitability, SG, OCF, tangibility, firm age (FA) dan ukuran perusahaan berpengaruh positif terhadap investasi modal kerja. 
LEV ditemukan berpengaruh negatif dengan investasi modal kerja.

Penelitian terkait faktor determinasi dari kebutuhan modal kerja terdapat variasi hasil. Azeem \& Marsap (2015) melakukan penelitian faktor determinasi kebutuhan modal kerja pada perusahaan non keuangan Pakistan dengan memperhatikan variabel-variabel ekonomi dan keuangan. Hasilnya menunjukkan bahwa siklus operasi, OCF, ROA, debt dan ukuran perusahaan signifikan terhadap kebutuhan modal kerja perusahaan. Aktivitas ekonomi dan SG ditemukan tidak signifikan terhadap kebutuhan modal kerja perusahaan.

Hal ini didukung oleh penelitian yang dilakukan oleh Singh \& Kumar (2017) menganalisis pengaruh berbagai faktor determinasi kebutuhan modal kerja pada UKM di India pada tahun 2010-2014. ROA dan SG berpengaruh positif terhadap kebutuhan modal kerja. Asset tangibility (FATA), OCF, debt ratio berpengaruh negatif terhadap kebutuhan modal kerja. Ukuran perusahaan dan umur perusahaan tidak berpengaruh terhadap kebutuhan modal kerja. Berdasar uraian penelitian sebelumnya penulis ingin meneliti dengan menggunakan hipotesis sebagai berikut:

\section{H1: Return on assets berpengaruh positif terhadap kebutuhan modal kerja}

Pengelolaan terhadap aktiva yang menjadi komponen modal kerja, membuat manajemen harus berhati-hati dalam mengambil keputusan terkait operasional perusahaan. Diharapkan dengan hal tersebut dapat meningkatkan laba dan nantinya perusahaan dapat menghasilkan tingkat return yang tinggi terhadap pengelolaan aktivanya (Kasmir, 2010). ROA menjadi faktor yang penting dalam determinasi dari kebutuhan modal kerja perusahaan. Perusahaan dengan ROA yang tinggi memiliki modal kerja yang cukup serta lebih memungkinkan dapat dialokasikan untuk investasi jangka pendek maupun jangka panjang. Akinlo (2012), Azeem \& Marsap (2015), Singh \& Kumar (2017) melakukan penelitian faktor determinasi kebutuhan modal kerja yang menguji ROA terhadap kebutuhan modal kerja dan hasilnya adalah signifikan positif.

H2: Sales growth berpengaruh positif terhadap kebutuhan modal kerja

Pertumbuhan penjualan menandakan keberhasilan perusahaan dalam berinvestasi periode masa lalu dan dapat dijadikan sebagai prediksi pertumbuhan di masa yang akan datang. Perusahaan harus bisa memprediksikan berapa kemungkinan laba yang akan didapatkan dengan mengetahui seberapa besar pertumbuhan penjualan. Dengan adanya pertumbuhan penjualan maka piutang dan kas diharapkan dapat naik sehingga menjadi tambahan untuk kebutuhan modal kerja. Onaolapo \& Kajola (2015) berpendapat bahwa sebuah perusahaan mengantisipasi pertumbuhan dan cenderung meningkatkan investasi dalam persediaan. Akinlo (2012), Wasiuzzaman \& Arumugam (2013), Singh \& Kumar (2017) melakukan penelitian faktor determinasi kebutuhan modal kerja yang menguji pengaruh growth opportunity terhadap kebutuhan modal kerja dan hasilnya adalah signifikan positif.

H3: Firm size berpengaruh positif terhadap kebutuhan modal kerja

Perusahaan dengan ukuran yang besar yaitu memiliki total aktiva dengan jumlah yang besar. Perusahaan yang memiliki total aktiva yang besar lebih cenderung mendapatkan perhatian dan prioritas dari pada pihak ekternal seperti investor dan kreditur jika dibandingkan dengan perusahaan kecil. Investor lebih cenderung ingin menginvestasikan modal kepada perusahaan yang berukuran besar sehingga diharapkan adanya pengembalian terhadap investasi tersebut. Chiou et al. (2006), Akinlo (2012), Narender et al. (2008) melakukan penelitian faktor determinasi kebutuhan modal kerja yang menguji pengaruh ukuran perusahaan terhadap kebutuhan modal kerja dan hasilnya adalah signifikan positif.

\section{H4: Firm age berpengaruh positif terhadap kebutuhan modal kerja}

Semakin lama umur perusahaan berarti menunjukkan bahwa perusahaan tersebut tetap mampu beroperasi dan menghasilkan laba yang lebih jika dibandingkan dengan perusahaan yang baru berdiri. Perusahaan yang telah lama berdiri dapat memperoleh dana dari eksternal yang relatif mudah jika dibandingkan dengan perusahaan yang baru berdiri (Singh \& Kumar, 2017). Chiou et al. (2006), Wasiuzzaman \& Arumugam (2013) melakukan penelitian faktor determinasi kebutuhan modal kerja yang menguji pengaruh umur perusahaan terhadap kebutuhan modal kerja dan hasilnya adalah signifikan positif.

H5: Assets tangibility berpengaruh negatif terhadap kebutuhan modal kerja 
Aktiva berwujud merupakan aktiva yang dimiliki untuk digunakan dalam kegiatan operasional perusahaan sehari-hari dan diharapkan digunakan dalam suatu periode tertentu. Menurut Fazzri \& Petersen (1993), jika investasi dalam aktiva berwujud tinggi maka akan mengurangi jumlah dana modal kerja yang dibutuhkan oleh perusahaan. Perusahaan cenderung memilih investasi dalam bentuk aktiva berwujud yang nantinya akan memiliki manfaat dalam keseharian perusahaan dalam menjalankan kegiatan operasional. Singh \& Kumar (2017) melakukan penelitian terkait faktor determinasi kebutuhan modal kerja menyatakan bahwa aktiva berwujud perusahaan berpengaruh negatif terhadap tingkat kebutuhan modal kerja.

H6: Operating cash flow berpengaruh positif terhadap kebutuhan modal kerja

Arus kas operasi menunjukkan kas yang masuk dan keluar dalam kegiatan operasional perusahaan. Kondisi kas perusahaan yang meningkat merupakan posisi yang bagus untuk melakukan investasi dalam modal kerja sehingga akan menambah modal kerja yang ada. Wasiuzzaman \& Arumugam (2013) dan Narender et al. (2008) melakukan analisis faktor determinasi kebutuhan modal kerja menyatakan bahwa arus kas operasi berpengaruh positif terhadap kebutuhan modal kerja perusahaan.

\section{H7: Leverage berpengaruh negatif terhadap kebutuhan modal kerja}

Leverage menurut Brigham \& Houston (2007) merupakan rasio yang mengukur sejauh mana segala aktivitas pendanaan yang digunakan oleh perusahaan menggunakan hutang. Leverage merupakan driver dari modal kerja, karena penggunaan hutang dapat mempengaruhi tingkat modal kerja perusahaan. Perusahaan yang menggunakan hutang untuk modal kerjanya lebih memilih untuk diinvestasikan ke dalam bentuk aktiva tetap atau yang lainnya sehingga dapat menunjang kegiatan operasional yang ada. Chiou et al. (2006), Akinlo (2012), Singh \& Kumar (2017) melakukan penelitian terkait faktor determinasi kebutuhan modal kerja menyatakan bahwa leverage berpengaruh negatif terhadap kebutuhan modal kerja.

Berdasarkan penjelasan dari pengembangan hipotesis di atas maka model penelitiannya adalah sebagai berikut:

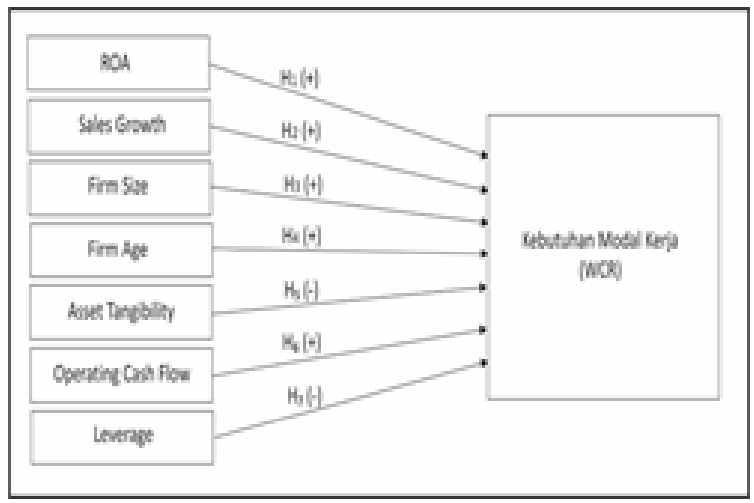

Gambar 1 Model Penelitian

\section{Metode Penelitian}

\section{Jenis data dan sampel penelitian}

Penelitian ini merupakan penelitian kuantitatif karena menggunakan pendekatan yang sistematis terhadap objek dengan teori-teori dan hipotesis mengenai sebuah fenomena. Penelitian ini menggunakan data sekunder berupa data perusahaan yang diperoleh dari www.idx.co.id dan www.wrdsweb.wharton.upenn.edu. Objek penelitian ini adalah perusahaan manufaktur yang terdaftar di Bursa Efek Indonesia periode 2012-2015. Penarikan sampel pada penelitian ini menggunakan purposive sampling yaitu berdasarkan kriteria-kriteria khusus yang sudah ditentukan. Adapun kriterianya sebagai berikut: sampel yang dipilih adalah perusahaan manufaktur yang terdaftar di Bursa Efek Indonesia periode 20122015, perusahaan sampel secara berturut-turut melaporkan adanya laba selama tahun pengamatan, annual report menggunakan mata uang rupiah. Sampel yang didapat pada penelitian ini sejumlah 212 perusahaan.

\section{Hasil dan Pembahasan}

\section{Statistik Deskriptif}

Berdasarkan hasil uji statistik deskriptif dapat dilihat bahwa terdapat 8 variabel pada penelitian ini yaitu return on assets, sales growth, ukuran perusahaan, umur perusahaan, assets tangibility, operating cash flow, dan leverage dengan jumlah sampel keseluruhan sejumlah 212 perusahaan manufaktur. Nilai rata-rata WCR menandakan bahwa perusahaan manufaktur di Indonesia periode 2012- 
2015 memiliki kebutuhan modal kerja sebesar 0,282. Nilai maksimal menunjukkan kebutuhan modal kerja perusahaan manufaktur paling tinggi sebesar 0,813 sedangkan nilai terendah menunjukkan sebesar -0,346. Nilai standar deviasi atau ketimpangannya sebesar 0,234 menunjukkan rata-rata penyimpangan kebutuhan modal kerja.

Nilai rata-rata ROA menandakan bahwa perusahaan manufaktur di Indonesia periode 2012 2015 memiliki rata-rata tingkat profitabilitas sebesar 0,108. Nilai maksimal menunjukkan nilai profitabilitas perusahaan manufaktur paling tinggi sebesar 0,657 sedangkan nilai terendah 0,000 menunjukkan nilai profitabilitas perusahaan manufaktur yang paling rendah. Nilai standar deviasi atau ketimpangannya sebesar 0,104 menunjukkan rata-rata penyimpangan $\mathrm{ROA}$.

Nilai rata-rata SG menandakan bahwa perusahaan manufaktur di Indonesia periode 2012-2015 memiliki rata-rata tingkat pertumbuhan penjualan sebesar 0,109 . Nilai maksimal menunjukkan pertumbuhan penjualan perusahaan manufaktur paling tinggi sebesar 1,540 sedangkan nilai terendah $-0,500$ menunjukkan pertumbuhan penjualan perusahaan manufaktur yang paling rendah. Nilai standar deviasi atau ketimpangannya sebesar 0,193 menunjukkan rata-rata penyimpangan $S G$.

Nilai rata-rata FS menandakan bahwa perusahaan manufaktur di Indonesia periode 2012-2015 memiliki rata-rata tingkat ukuran perusahaan sebesar 21,352. Nilai maksimal menunjukkan ukuran perusahaan manufaktur paling tinggi sebesar 26,226 sedangkan nilai terendah 18,672 menunjukkan ukuran perusahaan manufaktur yang paling rendah. Nilai standar deviasi atau ketimpangannya sebesar 1,636 menunjukkan rata-rata penyimpangan FS.

Nilai rata-rata FA menandakan bahwa perusahaan manufaktur di Indonesia periode 2012-2015 memiliki rata-rata umur 3,595. Nilai maksimal menunjukkan umur perusahaan manufaktur paling tinggi sebesar 4,736 sedangkan nilai terendah 1,792 menunjukkan ukuran perusahaan manufaktur yang paling rendah. Nilai standar deviasi atau ketimpangannya sebesar 0,486 menunjukkan rata-rata penyimpangan FA.

Nilai rata-rata FATA menandakan bahwa perusahaan manufaktur di Indonesia periode 20122015 memiliki tingkat rata-rata aktiva berwujud sebesar 0,416. Nilai maksimal menunjukkan aktiva berwujud perusahaan manufaktur paling tinggi sebesar 0,868 sedangkan nilai terendah 0,089 menunjukkan aktiva berwujud perusahaan manufaktur yang paling rendah. Nilai standar deviasi atau ketimpangannya sebesar 0,174 menunjukkan rata-rata penyimpangan FATA.

Nilai rata-rata OCF menandakan bahwa perusahaan manufaktur di Indonesia periode 2012-2015 memiliki tingkat rata-rata arus kas operasi sebesar 0,106 . Nilai maksimal menunjukkan arus kas operasi perusahaan manufaktur paling tinggi sebesar 0,662 sedangkan nilai terendah $-0,163$ menunjukkan arus kas operasi perusahaan perusahaan manufaktur yang paling rendah. Nilai standar deviasi atau ketimpangannya sebesar 0,174 menunjukkan rata-rata penyimpangan OCF.

Nilai rata-rata LEV menandakan bahwa perusahaan manufaktur di Indonesia periode 2012-2015 memiliki tingkat rasio hutang sebesar 0,404. Nilai maksimal menunjukkan rasio hutang perusahaan manufaktur paling tinggi sebesar 0,881 sedangkan nilai terendah 0,121 menunjukkan rasio hutang perusahaan perusahaan manufaktur yang paling rendah. Nilai standar deviasi atau ketimpangannya sebesar 0,174 menunjukkan rata-rata penyimpangan LEV.

\begin{tabular}{llllll}
\multicolumn{7}{c}{ Tabel 1 Statistik Deskriptif } \\
\hline \multicolumn{7}{c}{ N } & Minimum & Maximum & Mean & Std. Deviation \\
\hline WCR & 212 & $-0,346$ & 0,813 & 0,282 & 0,234 \\
ROA & 212 & 0,000 & 0,657 & 0,108 & 0,104 \\
SG & 212 & $-0,500$ & 1,540 & 0,109 & 0,193 \\
FS & 212 & 18,672 & 26,226 & 21,352 & 1,636 \\
FA & 212 & 1,792 & 4,736 & 3,595 & 0,486 \\
FATA & 212 & 0,089 & 0,868 & 0,416 & 0,174 \\
OCF & 212 & $-0,163$ & 0,662 & 0,106 & 1,121 \\
LEV & 212 & 0,121 & 0,881 & 0,404 & 0,174
\end{tabular}

Keterangan: Tabel ini mempresentasikan hasil uji statistik. Seluruh hasil dari dari masing-masing variabel adalah dalam bentuk satuan. Variabel dependen WCR = Kebutuhan Modal Kerja). Variabel Independen (ROA = Return on Assets, $\mathrm{SG}=$ Sales Growth, FS $=$ Firm Size, FA $=$ Firm Age, FATA $=$ Assets Tangibility, OCF = Operating Cash Flow, LEV = Leverage).

\section{Hasil Uji Model Eviews}

Dari hasil uji H1 menunjukkan cross section $f$ sebesar $0.0075<0.05$ maka model yang terpilih adalah fixed effect. Cross section random sebesar $0.725>0.005$ maka model yang terpilih adalah random effect, maka ketika penentuan model yang cocok untuk H1 harus dilanjutkan dengan uji LM dengan membandingkan LM hitung dengan chi squared table. LM hitung sebesar 267.2853>239.403 dapat disimpulkan bahwa untuk pengujian $\mathrm{H} 1$ model yang terpilih adalah random effect.

Dari hasil uji $\mathrm{H} 2$ menunjukkan cross section $f$ sebesar $0.0087<0.05$ maka model yang terpilih adalah fixed effect. Cross section random sebesar $0.3655>0.05$ maka model yang terpilih adalah random 
effect, maka ketika penentuan model yang cocok untuk H2 harus dilanjutkan dengan uji LM dengan membandingkan LM hitung dengan chi squared table. LM hitung sebesar 255.4736>239.4039 dapat disimpulkan bahwa untuk pengujian $\mathrm{H} 2$ model yang terpilih adalah random effect.

Dari hasil uji $\mathrm{H} 3$ menunjukkan cross section $f$ sebesar $0.0153<0.05$ maka model yang terpilih adalah fixed effect. Cross section random sebesar $0.1878>0.05$ maka model yang terpilih adalah random effect, maka ketika penentuan model yang cocok untuk H3 harus dilanjutkan dengan uji LM dengan membandingkan LM hitung dengan chi squared table. LM hitung sebesar 264.6163>239.403 dapat disimpulkan bahwa untuk pengujian H3 model yang terpilih adalah random effect.

Dari hasil uji $\mathrm{H} 4$ menunjukkan cross section $f$ sebesar $0.0064<0.05$ maka model yang terpilih adalah fixed effect. Cross section random sebesar $0.0472<0.05$ maka model yang terpilih adalah fixed effect, maka dapat disimpulkan bahwa untuk pengujian $\mathrm{H} 4$ model yang terpilih adalah fixed effect.

Dari hasil uji H5 menunjukkan cross section $f$ sebesar $0.4303>0.05$ maka model yang terpilih adalah common effect. Cross section random sebesar 0.9845 $>0.05$ maka model yang terpilih adalah random effect, maka ketika penentuan model yang cocok untuk H5 harus dilanjutkan dengan uji LM dengan membandingkan LM hitung dengan chi squared table. LM hitung sebesar 235.9545<239.403 dapat disimpulkan bahwa untuk pengujian H5 model yang terpilih adalah common effect.

Dari hasil uji H6 menunjukkan cross section $f$ sebesar $0.0061<0.05$ maka model yang terpilih adalah fixed effect. Cross section random sebesar 0.7769>0.05 maka model yang terpilih adalah random effect, maka ketika penentuan model yang cocok untuk H6 harus dilanjutkan dengan uji LM dengan membandingkan LM hitung dengan chi squared table. LM hitung sebesar 265.4372>239.403 dapat disimpulkan bahwa untuk pengujian H6 model yang terpilih adalah random effect.

Dari hasil uji $\mathrm{H} 7$ menunjukkan cross section $f$ sebesar $0.0016<0.05$ maka model yang terpilih adalah fixed effect. Cross section random sebesar $0.4081>0.05$ maka model yang terpilih adalah random effect, maka ketika penentuan model yang cocok untuk H7 harus dilanjutkan dengan uji LM dengan membandingkan LM hitung dengan chi squared table. LM hitung sebesar 261.2175>239.403 dapat disimpulkan bahwa untuk pengujian $\mathrm{H} 7$ model yang terpilih adalah random effect.
Tabel 2 Uji Chow, Uji Housman dan Uji LM

\begin{tabular}{lllll}
\hline \multirow{2}{*}{ Hipotesis } & \multicolumn{3}{c}{ Nilai Probabilitas } & Keputusan \\
\cline { 2 - 4 } & Cross-section F & $\begin{array}{c}\text { Cross-section } \\
\text { Random }\end{array}$ & LM Hitung & \\
\hline ROA (H1) & 0.0075 & 0.7258 & 267.2853 & Fandom Effect \\
SG (H2) & 0.0087 & 0.3655 & 255.4736 & Alandom Effect \\
FS (HS) & 0.0153 & 0.1878 & 264.6163 & Alandom Effect \\
FA (H4) & 0.0064 & 0.0472 & - & Fixed Effect \\
FATA (MS) & 0.4304 & 0.9845 & 235.9545 & Common Effect \\
OCF (H6) & 0.0061 & 0.77699 & 265.4372 & Fandom Effect \\
LEV (H7) & 0.0016 & 0.4081 & 261.2175 & Alandom Effect \\
\hline
\end{tabular}

Return on Asset berpengaruh positif terhadap Kebutuhan Modal Kerja (H1)

$$
\text { WCRit }=0.242076+0.366873 \text { ROAit }
$$

Nilai rata-rata kebutuhan modal kerja sebesar 0.242076 akan meningkat sebesar 0.366873 jika variabel return on asset naik sebesar satu satuan dengan asumsi variabel lain tetap. Berdasarkan hasil uji $\mathrm{H} 1$ return on asset berpengaruh signifikan positif terhadap kebutuhan modal kerja menunjukkan bahwa $\mathrm{H} 1$ terdukung. Hasil random effect pada H1 menunjukkan bahwa nilai adjusted $R$-squared 0.022560 yang artinya kebutuhan modal kerja dipengaruhi oleh return on asset sebesar $2.2 \%$ dan sisanya dipengaruhi oleh variabel lain. Untuk nilai prob(F-statistic) sebesar 0.016248 yang artinya variabel independen berpengaruh terhadap variabel dependen karena 0.016248>0.05. Nilai coefficient dari return on asset sebesar 0.366873 dan nilai probabilitas dari ROA sebesar 0.0165 nilai tersebut lebih kecil dari nilai $\alpha(0.05)$ sehingga dapat disimpulkan bahwa return on asset berpengaruh signifikan positif terhadap kebutuhan modal kerja.

Tabel 3 Uji Model Random Effect (H1)

\begin{tabular}{ccccc}
\hline Variable & Coefficient & Std. Error & t-Statistic & Prob. \\
\hline$C$ & 0.242076 & 0.025259 & 9.583697 & 0.0000 \\
ROA? & 0.366973 & 0.151740 & 2.417764 & 0.0165 \\
\hline & Effects Specification & & \\
\hline R-squared & 0.027193 & & \\
Adiusted R-squared & 0.022560 & & \\
Prob(f-statistic) & 0.016248 & & \\
\hline
\end{tabular}

Sales Growth berpengaruh positif terhadap Kebutuhan Modal Kerja (H2)

$$
\text { WCRit }=0.294381-0.116592 \text { SGit }
$$

Nilai rata-rata kebutuhan modal kerja 0.294381 akan menurun sebesar 0.116592 jika variabel sales growth mengalami penurunan sebesar satu satuan 
dengan asumsi variabel lain tetap. Berdasarkan hasil uji $\mathrm{H} 2$, sales growth berpengaruh signifikan positif terhadap kebutuhan modal kerja menunjukkan bahwa $\mathrm{H} 2$ tidak terdukung. Hasil random effect pada $\mathrm{H} 2$ menunjukkan bahwa nilai adjusted $R$-squared 0.004680 yang artinya kebutuhan modal kerja dipengaruhi oleh sales growth sebesar $0.4 \%$ dan sisanya dipengaruhi oleh variabel lain. Untuk nilai prob(F-statistic) sebesar 0.159597 yang artinya variabel independen tidak berpengaruh terhadap variabel dependen karena 0.159597>0.05. Nilai coefficient dari sales growth sebesar -0.116592 dan nilai probabilitas dari SG sebesar 0.1598 nilai tersebut lebih besar dari nilai $\alpha(0.05)$ sehingga dapat disimpulkan bahwa sales growth tidak berpengaruh signifikan positif terhadap kebutuhan modal kerja.

Tabel 4 Uji Model Random Effect (H2)

\begin{tabular}{crrrr}
\hline Variable & Coefficient & Std. Error & t-Statistic & Prob. \\
\hline C & 0.294381 & 0.021214 & 13.87695 & 0.0000 \\
SG? & -0.116592 & 0.082641 & -1.410824 & 0.1598 \\
\hline \multicolumn{5}{c}{ Effects Specification } \\
R-squared & 0.009397 & \\
Adjusted R-squared & 0.004680 & & \\
Prob(F-statistic) & 0.159597 & & \\
\hline
\end{tabular}

Firm Size berpengaruh positif terhadap Kebutuhan Modal (H3)

$$
\text { WCRit }=0.747460-0.021814 \text { SIZEit }
$$

Nilai rata-rata kebutuhan modal kerja 0.747460 akan menurun sebesar 0.021814 jika variabel firm size mengalami penurunan sebesar satu satuan dengan asumsi variabel lain tetap. Berdasarkan hasil uji $\mathrm{H} 3$ firm size berpengaruh signifikan positif terhadap kebutuhan modal kerja menunjukkan bahwa $\mathrm{H} 3$ tidak terdukung, karena koefisien dari firm size adalah negatif. Hasil random effect pada $\mathrm{H} 3$ menunjukkan bahwa nilai adjusted $R$-squared 0.017619 yang artinya kebutuhan modal kerja dipengaruhi oleh firm size sebesar $1.7 \%$ dan sisanya dipengaruhi oleh variabel lain. Untuk nilai prob(F-statistic) sebesar 0.029824 yang artinya variabel independen berpengaruh terhadap variabel dependen karena $0.029824<0.05$. Nilai coefficient dari firm size sebesar -0.021814 dan nilai probabilitas dari firm size sebesar 0.0295 nilai tersebut lebih kecil dari nilai $\alpha(0.05)$ sehingga dapat disimpulkan bahwa firm size berpengaruh signifikan negatif terhadap kebutuhan modal kerja.
Tabel 5 Uji Model Random Effect (H3)

\begin{tabular}{crrrr}
\hline Variable & Coefficient & Std. Error & t-Statistic & Prob. \\
\hline C & 0.747460 & 0.213391 & 3.502776 & 0.0006 \\
FS? & -0.021814 & 0.009956 & -2.191129 & 0.0295 \\
\hline \multicolumn{5}{c}{ Effects Specification } \\
\hline R-squared & 0.022275 & & \\
Adjusted R-squared & 0.017619 & & \\
Prob(F-statistic) & 0.029824 & & \\
\hline
\end{tabular}

Firm Age berpengaruh positif terhadap Kebutuhan Modal Kerja (H4)

$$
\text { WCRit }=0.215258+0.018473 \text { AGEit }
$$

Nilai rata-rata kebutuhan modal kerja sebesar 0.215258 akan meningkat sebesar 0.018473 jika variabel firm age naik sebesar satu satuan dengan asumsi variabel lain tetap. Berdasarkan hasil uji $\mathrm{H} 4$ firm age berpengaruh signifikan positif terhadap kebutuhan modal kerja menunjukkan bahwa $\mathrm{H} 4$ tidak terdukung. Hasil random effect pada $\mathrm{H} 4$ menunjukkan bahwa nilai adjusted $R$-squared adalah -0.016302 yang artinya kebutuhan modal kerja dipengaruhi oleh firm age sebesar $0 \%$. Untuk nilai prob(F-statistic) sebesar 0.153878 yang artinya variabel independen tidak berpengaruh terhadap variabel dependen karena $0.153878>0.05$. Nilai coefficient dari firm age sebesar 0.018473 dan nilai probabilitas dari firm age sebesar 0.5808 nilai tersebut lebih besar dari nilai $\alpha(0.05)$ sehingga dapat disimpulkan bahwa firm age tidak berpengaruh signifikan terhadap kebutuhan modal kerja.

Tabel 6 Uji Model Random Effect (H4)

\begin{tabular}{ccccc}
\hline Variable & Coefficient & Std. Error & t-Statistic & Prob. \\
\hline C & 0.215258 & 0.121171 & 1.776487 & 0.0771 \\
FA? & 0.018473 & 0.033398 & 0.553119 & 0.5808 \\
\hline \multicolumn{5}{c}{ Effects Specification } \\
\hline R-squared & 0.002965 & & \\
Adjusted R-squared & -0.016302 & & \\
Prob(F-statistic) & 0.153878 & & \\
\hline
\end{tabular}

Asset Tangibility berpengaruh negatif terhadap Kebutuhan Modal Kerja (H5)

$$
\text { WCRit }=0.698231-1.000654 \text { FATAit }
$$

Nilai rata-rata kebutuhan modal kerja 0.698231 akan menurun sebesar 1.000654 jika variabel assets 
tangibility mengalami penurunan sebesar satu satuan dengan asumsi variabel lain tetap. Berdasarkan hasil uji H5, assets tangibility berpengaruh signifikan negatif terhadap kebutuhan modal kerja menunjukkan bahwa H5 terdukung. Hasil random effect pada H5 menunjukkan bahwa nilai adjusted $R$-squared 0.553089 yang artinya kebutuhan modal kerja dipengaruhi oleh assets tangibility sebesar 55\% dan sisanya dipengaruhi oleh variabel lain. Untuk nilai prob(F-statistic) sebesar 0.000000 yang artinya variabel independen berpengaruh terhadap variabel dependen karena $0.000000<0.05$. Nilai coefficient dari assets tangibility sebesar -1.000654 dan nilai probabilitas dari assets tangibility sebesar 0.0000 nilai tersebut lebih kecil dari nilai $\alpha(0.05)$ sehingga dapat disimpulkan bahwa assets tangibility berpengaruh signifikan negatif terhadap kebutuhan modal kerja.

Tabel 7 Uji Model Random Effect (H5)

\begin{tabular}{lrrrr}
\hline \hline Variable & Coefficient & Std. Error & t-Statistic & Prob. \\
\hline \hline C & 0.698231 & 0.027884 & 25.04079 & 0.0000 \\
FATA? & -1.000654 & 0.061805 & -16.19043 & 0.0000 \\
\hline \hline \multicolumn{5}{c}{ Effects Specification } \\
\hline \hline R-squared & 0.555207 & & \\
Adjusted R-squared & 0.553089 & & \\
Prob(F-statistic) & 0.000000 & & \\
\hline \hline
\end{tabular}

Operating Cash Flow berpengaruh positif terhadap Kebutuhan Modal Kerja (H6)

$$
\text { WCRit }=0.275502+0.058337 \text { OCFit }
$$

Nilai rata-rata kebutuhan modal kerja sebesar 0.275502 akan meningkat sebesar 0.058337 jika variabel operating cash flow naik sebesar satu satuan dengan asumsi variabel lain tetap. Berdasarkan hasil uji H6, operating cash flow berpengaruh signifikan positif terhadap kebutuhan modal kerja menunjukkan bahwa H6 tidak terdukung. Hasil random effect pada H6 menunjukkan bahwa nilai adjusted $R$-squared adalah -0.003832 yang artinya kebutuhan modal kerja dipengaruhi oleh operating cash flow sebesar $0 \%$. Untuk nilai prob(F-statistic) sebesar 0.659617 yang artinya variabel independen tidak berpengaruh terhadap variabel dependen karena 0.659617>0.05. Nilai coefficient dari operating cash flow sebesar 0.058337 dan nilai probabilitas dari operating cash flow sebesar 0.6603 nilai tersebut lebih besar dari nilai $\alpha(0.05)$ sehingga dapat disimpulkan bahwa operating cash flow tidak berpengaruh signifikan terhadap kebutuhan modal kerja.
Tabel 8 Uji Model Random Effect (H6)

\begin{tabular}{lcccc}
\hline Variable & Coefficient & Std. Error & t-Statistic & Prob. \\
\hline C & 0.275502 & 0.024111 & 11.42623 & 0.0000 \\
OCF? & 0.058337 & 0.132554 & 0.440102 & 0.6603 \\
& & & \\
\hline & Effects Specification & \\
\hline R-squared & 0.000926 & & \\
Adjusted R-squared & -0.003832 & & \\
Prob(F-statistic) & 0.659617 & & \\
\hline \hline
\end{tabular}

Leverage berpengaruh negatif terhadap Kebutuhan Modal Kerja (H7)

$$
\text { WCRit }=0.650033-0.911903 \text { LEVit }
$$

Nilai rata-rata kebutuhan modal kerja 0.650033 akan menurun sebesar 0.911903 jika variabel leverage mengalami penurunan sebesar satu satuan dengan asumsi variabel lain tetap. Berdasarkan hasil uji $\mathrm{H} 7$ leverage berpengaruh signifikan negatif terhadap kebutuhan modal kerja menunjukkan bahwa $\mathrm{H} 7$ terdukung. Hasil random effect pada $\mathrm{H} 7$ menunjukkan bahwa nilai adjusted $R$-squared 0.481196 yang artinya WCR dipengaruhi oleh leverage sebesar $48 \%$ dan sisanya dipengaruhi oleh variabel lain. Untuk nilai prob(F-statistic) sebesar 0.000000 yang artinya variabel independen berpengaruh terhadap variabel dependen karena $0.000000<0.05$. Nilai coefficient dari leverage sebesar -0.911903 dan nilai probabilitas dari leverage sebesar 0.0000 nilai tersebut lebih kecil dari nilai $\alpha(0.05)$ sehingga dapat disimpulkan bahwa leverage berpengaruh signifikan negatif terhadap kebutuhan modal kerja.

Tabel 9 Uji Model Random Effect (H7)

\begin{tabular}{lcccc}
\hline \multicolumn{1}{c}{ Variable } & Coefficient & Std. Error & t-Statistic & Prob. \\
\hline C & 0.650033 & 0.030030 & 21.64630 & 0.0000 \\
LEV? & -0.911903 & 0.065068 & -14.01459 & 0.0000 \\
\hline \hline & Effects Specification & & \\
\hline R-squared & 0.483655 & & \\
Adjusted R-squared & 0.481196 & & \\
Prob(F-statistic) & 0.000000 & & \\
\hline \hline
\end{tabular}

\section{Analisis Data}

Berikut adalah tabel ringkasan hasil uji hipotesis penelitian: 
Tabel 10 Ringkasan Hasi Uji Hipotesis

\begin{tabular}{ccl}
\hline Hipotesis & Sig. & \multicolumn{1}{c}{ Kesimpulan } \\
\hline H1 & 0.0165 & Hipotesis terdukung \\
H2 & 0.1598 & Hipotesis tidak terdukung \\
H3 & 0.0295 & Hipotesis tidak terdukung \\
H4 & 0.5808 & Hipotesis tidak terdukung \\
H5 & 0.0000 & Hipotesis terdukung \\
H6 & 0.6603 & Hipotesis tidak terdukung \\
H7 & 0.0000 & Hipotesis terdukung \\
\hline Signifikan pada level $5 \%(\alpha=0.05)$ &
\end{tabular}

Signifikan pada level 5\% $(\alpha=0.05)$

Return on Asset berpengaruh positif terhadap Kebutuhan Modal Kerja

Hasil pengujian menunjukkan bahwa H1 terdukung. Hasil tersebut menandakan bahwa pengelolaan aktiva yang efektif akan meningkatkan profitabilitas dan menghasilkan return yang tinggi terhadap pengelolaan aktiva. Perusahaan yang memiliki profitabilitas yang tinggi dapat menjaga kebutuhan modal kerjanya yang tinggi dan membutuhkan investasi yang lebih besar dalam kebutuhan modal kerjanya. Hasil penelitian ini sejalan dengan penelitian yang dilakukan Wasiuzzaman \& Arumugam (2013), Azeem \& Marsap (2015), dan Onaolapo \& Kajola (2015) yang menyatakan bahwa return on asset berpengaruh signifikan positif terhadap kebutuhan modal kerja.

Sales Growth berpengaruh positif terhadap Kebutuhan Modal Kerja

Hasil pengujian menunjukkan bahwa $\mathrm{H} 2$ tidak terdukung. Hasil tersebut menandakan bahwa dengan adanya pertumbuhan penjualan tidak membuat kebutuhan modal kerja meningkat. Pertumbuhan penjualan tidak berarti menandakan adanya peningkatan kas. Macetnya pembayaran piutang yang menyebabkan perusahaan kekurangan kas untuk kegiatan operasional, sehingga perusahaan menggunakan sumber dana yang lain untuk menutupi kebutuhan modal kerjanya. Hal ini di dukung oleh penelitian Azeem \& Marsap (2015) yang menyatakan bahwa pertumbuhan penjualan tidak berpengaruh terhadap kebutuhan modal kerja. Data penjualan perusahaan manufaktur periode 2012-2015 tidak stabil sehingga peneliti tidak mendapatkan hasil yang baik untuk $\mathrm{H} 2$.

Firm Size berpengaruh positif terhadap Kebutuhan Modal Kerja

Hasil pengujian menunjukkan bahwa $\mathrm{H} 3$ tidak terdukung karena koefisien dari firm size adalah negatif. Hasil tersebut menandakan bahwa semakin maksimal aktiva yang dimiliki perusahaan untuk proses operasionalnya, tingkat kebutuhan modal kerja yang dibutuhkan telah tercukupi sehingga membuat kebutuhan modal kerja perusahaan menurun. Pernyataan ini didukung oleh penelitian Azeem \& Marsap (2015) yang menunjukkan bahwa ukuran perusahaan perpengaruh signifikan negatif terhadap kebutuhan modal kerja.

\section{Firm Age berpengaruh positif terhadap Kebutuhan} Modal Kerja

Hasil pengujian menunjukkan bahwa $\mathrm{H} 4$ tidak terdukung. Hasil tersebut menandakan bahwa umur perusahaan baik yang baru ataupun yang telah lama beroperasi tidak menandakan kebutuhan modal kerja mereka besar ataupun kecil. Tidak semua perusahaan yang telah lama beroperasi dapat menghasilkan laba secara konsisten dan mendapat pinjaman hutang dari pihak eksternal yang relatif besar sehingga akan menambah modal kerja perusahaan. Hasil penelitian ini sejalan dengan penelitian yang dilakukan Singh \& Kumar (2017) yang menyatakan bahwa umur perusahaan tidak berpengaruh terhadap kebutuhan modal kerja.

Asset Tangibility berpengaruh negatif terhadap Kebutuhan Modal Kerja

Hasil pengujian menunjukkan bahwa H5 terdukung. Hasil tersebut menandakan jika investasi dalam bentuk aktiva berwujud tinggi yaitu maksimal, dapat membantu aktivitas operasional perusahaan sehingga kebutuhan akan modal kerjanya berkurang karena telah tercukupi oleh investasi dalam bentuk aktiva berwujud. Hasil penelitian ini sejalan dengan penelitian yang dilakukan Singh \& Kumar (2017) yang menyatakan bahwa assets tangibility berpengaruh negatif terhadap kebutuhan modal kerja.

\section{Operating Cash Flow berpengaruh positif terhadap Kebutuhan Modal Kerja}

Hasil pengujian menunjukkan bahwa H6 tidak terdukung. Hasil tersebut menandakan bahwa perusahaan yang kondisi aliran kasnya meningkat, tingkat kebutuhan modal kerjanya belum dapat diketahui karena arus kas yang berasal dari hasil operasi bukan kas bersih yang didapatkan oleh perusahaan sehingga arus kas dari hasil operasi tidak dapat menentukan kondisi kebutuhan modal kerja 
perusahaan. Pernyataan ini didukung oleh penelitian Azeem \& Marsap (2015) yang menunjukkan bahwa operating cash flow tidak perpengaruh terhadap kebutuhan modal kerja.

\section{Leverage (LEV) berpengaruh negatif terhadap Kebutuhan Modal Kerja}

Hasil pengujian menunjukkan bahwa $\mathrm{H7}$ terdukung. Hasil tersebut menandakan bahwa semakin tinggi tingkat penggunaan hutang perusahaan maka kebutuhan modal kerjanya berkurang, karena kebutuhan modal kerjanya telah ditutupi oleh penggunaan hutang. Hal ini didukung oleh penelitian Chiou et al. (2006), Akinlo (2012), Wasiuzzaman \& Arumugam (2013) dan Singh \& Kumar (2017) yang menunjukkan bahwa leverage berpengaruh negatif terhadap kebutuhan modal kerja.

\section{Penutup}

Penelitian ini berisikan model untuk menguji pengaruh kinerja perusahaan terhadap kebutuhan modal kerja dengan menggunakan regresi data panel. Sampel yang digunakan adalah perusahaan manufaktur yang terdaftar di Bursa Efek Indonesia (BEI) yang berjumlah 212 periode tahun 2012-2015. Hasil penelitian menunjukkan bahwa kinerja perusahaan seperti return on assets (ROA), firm size (FS), assets tangibility (FATA), leverage (LEV) berpengaruh terhadap kebutuhan modal kerja (WCR) sedangkan sales growth (SG), operating cash flow (OCF) dan firm age (FA) tidak berpengaruh terhadap kebutuhan modal kerja (WCR).

Penelitian ini dapat dijadikan bahan referensi atau tambahan informasi untuk penelitian selanjutnya yang meneliti tentang kebutuhan modal kerja. Penelitian ini dapat dijadikan pertimbangan perusahaan untuk lebih meningkatkan kinerja perusahaan dan memperhatikan faktor-faktor dari determinasi kebutuhan modal kerja, sehingga kebutuhan modal kerja perusahan dapat tercukupi serta optimal. Bagi investor penelitian ini dapat menjadi bahan mengambil keputusan untuk berinvestasi ke perusahaan.

Pada penelitian ini penulis menemukan beberapa keterbatasan yang kemungkinan berpengaruh pada hasil penelitian dan di harapkan dapat diperbaiki pada penelitian selanjutnya. Keterbatasan yang ditemukan pada penelitian ini yaitu, peneliti hanya menggunakan variabel dependen dan independen yang sama dengan penelitian terdahulu, hanya menggunakan sampel perusahaan manufaktur, dan periode waktu yang digunakan hanya 4 tahun (2012-2015).

Berdasarkan hasil dari penelitian ini penulis menyarankan agar penelitian selanjutnya dapat memperluas ruang lingkup penelitian yaitu dengan menambahkan sampel penelitian sehingga tidak hanya meneliti perusahaan manufaktur saja, menambah jangka waktu penelitian dan menambah variabel kinerja perusahaan yang lainnya sehingga pengujian mendapatkan hasil yang lebih baik.

\section{References}

Akinlo. (2012). Determinants of Working Capital Requirements in Selected Quoted Companies in Nigeria. Journal of African Business, 13(1), 40-50.

Alexandri, M. B. (2009). Manajemen Keuangan Bisnis Teori dan Soal. Bandung: Alfabeta.

Azeem, M. M., \& Marsap, A. (2015). Determinant Factors and Working Capital Requirement. International Journal Of Economics and Finance.

Brigham, E. F., \& Houston, J. F. (2007). Fundamentals of Financial Management, Eleventh Edition. USA: Thomson South Western.

Caballero, S. B., Teruel, P. G., \& Solano, M. P. (2015). Financing of Working Capital Requirement, Financial Flexibility and SME Performance. Journal of Business Economics and Management.

Chiou, Cheng, \& Wu. (2006). The Determinants of Working Capital Mangement. Journal of American Academy of Business, 10(1), 149-155.

Fahmi, I. (2015). Pengantar Manajemen Keuangan Teori dan Soal Jawaban. Bandung: Alfabeta.

Communities, C. O. (2001-2002). Communication From the Commission.

Fazzari, \& Petersen. (1993). Working Capital and Fixed Investment: New Evidence on Financing Constraints. The RAND Journal of Economics, 328-342.

Ghozali, I. (2012). Aplikasi Analisis Multivariate dengan Program IBM SPSS 20. Semarang: Badan Penerbit UDIP.

Herry. (2009). Teori Akuntansi. Jakarta: Prenada Media Group.

Jeng-Ren, C., \& Han-Wen, W. (2006). The Determinants of Working Capita Management. Journal of American Academy of Business, 149-155.

Kasmir. (2010). Pengantar Manajemen Keuangan. Jakarta: Prenadamedia Grup.

Kaur, N., \& Kaur, J. (2014). Determinants of Working Capital Requirements of Automobile Industry India: A Study Of Passenger Vehicle Segment. Indian Accounting Association Past Presidents, 46(2), 117-126. 
Narender, V., Menon, S., \& Shwetha, V. (2008). Factor Determining Working Capital Management in Cemen Industry. South Asian Journal of Management, 15(4), 64-78.

Nazir, \& Afza. (2009). Working Capital Requirement and The Determining Factor in Pakistan. Journal of Applied Finance, 28-38.

Nobanee. (2011). Cash Conversion Cycle and Firm's Performance. Asian Review of Accounting, 147-156.

Onaolapo, \& Kajola. (2015). What are the Determinants if Working Capital Requirements of Nigerian Firms? Research Journal of Finance and Accounting, 118-127.

Qurashi, M., \& Zahoor, M. (2017). Working Capital Determinants for The UK. International Journal of Academic Research in Accounting, Finance and Management Sciences, 11-17.

Riyanto, B. (2008). Dasar Pembelajaran Akuntansi. Yogyakarta: 2008.

Singh, H. P., \& Kumar, S. (2017). Working Capital Requirements of Manufacturing SMEs: Evidence from Emerging Economy. International Business and Strategy.

Singhania. (2017). Working Capital Management and Firm Profitability: Evidence From Emerging Asian Countries. South Asian Journal of Business Studies.

Subramanyam, \& Wild. (2010). Analisis Laporan Keuangan, Edisi Sepuluh. Jakarta: Salemba Empat.

Wasiuzzaman, S. (2015). Working Capital and Firm Value in an Emerging Market. International Journal of Managerial.

Wasiuzzaman, S., \& Arumugam, V. C. (2013). Determinants of Working Capital Investment: A Study of Malaysian Publisted Firm. Australasian Accounting Business and Finance Journal, 63-68.

Weston, J. F., \& Copeland, T. E. (1985). Managerial Finance, 8th Ed. (Revised Edition). Los Angles: UCLA.

Widarjono, A. (2006). Ekonometrika: Teori dan Aplikasi untuk Ekonomi dan Bisnis, Edisi Kedua. Jakarta: UI. 